\title{
KAWISTARA
}

VOLUME 8

No. 1, 22 April 2018

Halaman 1-110

\section{ANALISIS MODEL 4AS \\ PADA KESEDIAAN MENGGUNAKAN KREDIT USAHA RAKYAT}

\author{
Rofikoh Rokhim \\ Universitas Indonesia \\ Email: rofikoh.rokhim@ui.ac.id \\ Iin Mayasari \\ Universitas Paramadina, Jakarta
}

\begin{abstract}
The development of the business world is not only dominated by big business actors, but also medium, small, and even micro. These micro-scale business actors are given the opportunity to thrive. People Business Credit Program (Kredit Usaha Rakyat) is applied as an innovative product that is specifically for micro entrepreneurs. This research aims to study four approaches of availability, affordability, awareness, and acceptability to analyze the willingness of using microfinance credit. This research uses a quantitative approach and multiple regression for the data analysis. The long-term goal of this research is to provide input for higher decision makers, companies, and local governments to develop better welfare and partnership strategies. This research found that the willingness of using microfinance credit was influenced by availability, awareness, and willingness to accept, except of affordability variable.
\end{abstract}

Keywords: Acceptability; Affordability; Availability; Awareness.

\begin{abstract}
ABSTRAK
Perkembangan dunia usaha tidak lagi didominasi oleh pelaku usaha besar, tetapi juga menengah, kecil bahkan mikro. Pelaku usaha yang berskala mikro ini diberikan kesempatan untuk berkembang. Kredit usaha rakyat (KUR) diterapkan sebagai produk inovatif yang ditujukan khusus bagi pengusaha mikro. Riset ini bertujuan untuk menganalisis pendekatan empat elemen yaitu ketersediaan, bisa terjangkau, kesadaran dan bisa diterima guna menganalisis kesediaan menggunakan KUR. Riset ini menggunakan pendekatan kuantitatif melalui survei dengan analisis regresi berganda. Tujuan jangka panjang penelitian ini adalah memberikan masukan bagi pembuat keputusan yang lebih tinggi yaitu perusahaan dan pemerintah daerah untuk menyusun strategi peningkatan kesejahteraan dan kemitraan yang lebih baik. Penelitian ini menjelaskan kesediaan nasabah KUR untuk menggunakannya dipengaruhi oleh variabel ketersediaan, variabel kesadaran, dan variabel kesediaan menerima.
\end{abstract}

Kata Kunci: Akseptabilitas; Kesadaran; Keterjangkauan; Ketersediaan. 


\section{PENGANTAR}

Pemerintah melalui Program Kredit Usaha Rakyat (KUR) berusaha untuk meningkatkan perekonomian masyarakat melalui sejumlah bank pemerintah. Ada syarat bagi bank untuk berperan sebagai Bank Pelaksana yang menyalurkan KUR, yaitu kredit bermasalah atau Non Performing Loan (NPL) usaha mikro dan kecil harus di bawah 5\%, dan portofolio kredit usaha mikro kecil di atas 5\% (Kusuma, 2016). Dengan adanya KUR, pengusaha mikro bisa memiliki keleluasaan dalam mengembangkan usaha yang sebelumnya tidak dimiliki sama sekali. Menurut studi Demirguc-Kunt dan Klapper (2012), masyarakat kecil di Jawa cenderung menerapkan arisan sebagai cara untuk mendapatkan pendanaan. Hal ini didukung dengan aspek penguatan komunitas dan dukungan budaya Timur yang menciptakan adanya kebersamaan. Persentase penggunaan institusi keuangan formal baru 20\% dari total populasi pada 2011. Dengan demikian, hal ini menjadi permasalahan sendiri dalam memengaruhi masyarakat kecil dalam memanfaatkan aksesibilitas kredit yang ditawarkan oleh perusahaan untuk meningkatkan kesejahteraan. Sethia (2005) berpendapat bahwa perusahaan yang memberikan kesempatan kepada pasar ini akan mendukung keberlangsungan jangka panjang perusahaan itu sendiri. Terkait dengan hal tersebut, riset ini bertujuan untuk menganalisis isu mengenai penggunaan KUR. Dengan mengoptimalkan penggunaan KUR, analisis untuk memahami perluasan usaha kecil dapat dipahami dengan lebih baik.

Isu produk keuangan mikro dalam hal ini KUR menjadi bagian penting dalam menunjang pemberdayaan masyarakat pelaku usaha mikro. Usaha Mikro adalah usaha ekonomi produktif milik orang perorangan dan/atau badan usaha perorangan yang memenuhi kriteria memiliki kekayaan bersih paling banyak Rp 50.000.000,00 tidak termasuk tanah dan bangunan tempat usaha, dan memiliki hasil penjualan tahunan paling banyak Rp300.000.000,00. KUR ini diberikan kepada pelaku usaha dengan plafon sampai dengan Rp 25.000.000,00. Kemudahan usaha yang diberikan oleh pemerintah ini bertujuan untuk memberikan kesempatan usaha termasuk peningkatan kesejahteraan masyarakat. Meskipun studi lain menunjukkan bahwa banyak program terkait untuk meningkatkan kesejahteraan masyarakat misalnya peningkatan sanitasi, pangan, energi, perumahan, kesehatan, pendidikan, dan penggunaan internet (Subrahmanyan dan Gomez-Arias, 2008). Shirazi dan Khan (2014) dan Ahmed (2009) berpendapat bahwa perhatian pada kredit keuangan mikro penting untuk mengurangi tingkat kemiskinan. Imai dkk (2010) juga berpendapat bahwa produk keuangan mikro mampu mengurangi kemiskinan rumah tangga. Selain itu, menurut Mader (2014), keuangan mikro dianggap sebagai cara untuk melepaskan kemiskinan yang paling bagus karena keuangan mikro merupakan hak kemanusiaan. Keuangan mikro dapat berupa pinjaman bank seperti yang dilakukan oleh Grameen Bank, bantuan dari Bank Dunia, pemerintah, dana filantrofi perusahaan, dana pribadi, perbankan, atau gerakan sosial terkait dengan praktik penerapan kredit mikro. Dengan demikian, diharapkan program ini bisa menunjang program pemerintah lainnya untuk meningkatkan kemampuan masyarakat mikro untuk lebih baik dan dapat berkontribusi dengan masyarakat.

Produk keuangan KUR ini merupakan produk inovatif yang ditujukan untuk pelaku usaha kecil dan mikro. Pemasar KUR akan menawarkan produk KUR ini agar dapat diadopsi oleh pelaku usaha. Penelitian-penelitian terdahulu sudah menggunakan teori-teori yang menjelaskan adopsi produk inovatif. Teori technology of acceptance model dari Davis (1989) menjelaskan pengaruh persepsi kegunaan, persepsi kemudahan penggunaan, dan norma subjektif pada perilaku adopsi produk; teori motivational model (Davis et al., 1992) yang menjelaskan pengaruh motivasi intrinsik dan motivasi ekstrinsik untuk adopsi teknologi baru dan penggunaan teknologi baru; teori planned behavior (Ajzen, 1991) menjelaskan pengaruh sikap pada perilaku, norma subjektif, dan kontrol perilaku yang dipersepsi pada adopsi penggunaan produk; kombinasi teori reasoned action dan technology of acceptance (Taylor dan Todd, 1995) yang 
merupakan model hibrida dalam menjelaskan adopsi perilaku inovatif; teori model of personal computer utilization (Thompson dkk, 1991) yang memprediksi penerimaan individu dan penggunaan sejumlah teknologi informasi; teori innovation diffusion (Rogers, 1995) yang menjelaskan mengenai penggunaan relatif, kemudahan penggunaan, citra, visibility, compatibility, demonstrability, sukarela dalam menggunakan produk teknologi inovatif; Teori Social Cognitive (Bandura, 1986) yang menjelaskan ekspektasi, self-efficacy dalam menganalisis penerimaan individu terhadap inovasi; Venkatesh $d k k$ (2003) mengusulkan model unified theory of acceptance and use of technology yang merupakan kombinasi sejumlah konsep penerimaan produk inovatif yang meliputi performance expectancy, effort expectancy, attitude toward technology using, social influence, facilitating condition, self-efficacy, anxiety, dan behavioral intention to use the system.

Menurut Anderson dan Billou (2007) dan Shah dan Desai (2013), konsep 4As lebih tepat untuk menganalisis perilaku masyarakat rural. Analisis penggunaan kredit keuangan mikro dengan konsep 4As yaitu availability, affordability, awareness, dan acceptability. Konsep 4As ini merupakan usulan Sheth dan Sisodia (2012) terkait dengan analisis adopsi produk. Hal ini penting sejalan dengan pemahaman yang lebih komprehensif terkait persepsi pelaku usaha mikro. Habib dan Zurawicki (2010) berpendapat bahwa penting untuk menganalisis kebutuhan dan kondisi masyarakat mikro sebagai target market dengan lebih terperinci terkait dengan ketepatan penawaran produk atau jasa. Konsep 4As yaitu availability, affordability, awareness, dan acceptability merupakan konsep yang mampu menjelaskan adopsi produk untuk masyarakat pelaku usaha mikro. Sheth dan Sisodia (2012) berpendapat bahwa konsep 4As ini sebenarnya sama dengan konsep bauran pemasaran yaitu produk (product), harga (price), distribusi (place), dan komunikasi (communication). Akan tetapi, konsep 4As ini lebih relevan untuk digunakan dalam membahas masyarakat rural atau untuk pelaku usaha mikro.

Konsep 4As menganalisis perilaku membuat keputusan masyarakat rural terkait dengan persepsi keberadaan produk atau jasa yang ditujukan kepadanya. Kemampuan dalam mengupayakan akuisisi produk atau jasa juga menjadi faktor dalam memudahkan untuk membuat keputusan. Kesadaran terkait dengan pengetahuan atau aspek kognitif juga memengaruhi masyarakat untuk memahami adanya produk keuangan mikro. Keinginan untuk menerima tawaran produk oleh masyarakat juga menjadi perhatian karena kemauan untuk menggunakan ini terkait dengan persepsi risiko. Persepsi risiko oleh masyarakat rural cukup tinggi karena menyadari latar belakang dengan tingkat pendidikan yang rendah dan minimnya pengetahuan yang menguatkan keyakinan. Memahami hal ini menjadi penting terkait dengan kesediaan menggunakan produk keuangan mikro.

Terkait dengan elemen 4As, yaitu availability, affordability, awareness, dan acceptability, masing-masing elemen ini bisa diupayakan untuk dikembangkan menjadi lebih baik. Aspek availability bisa mengarahkan pelaksana KUR untuk memberikan kemudahan bagi setiap pelaku bisnis mikro terkait akses kredit. Aspek affordability juga terkait dengan diberikannya kemudahan bagi pelaku bisnis mikro untuk mendapat kemudahan pinjaman terkait dengan rendahnya bunga. Aspek awareness terkait dengan penguatan sosialisasi program ini lebih intensif agar membuat pelaku usaha mikro mengetahui dengan baik manfaat produk KUR. Aspak acceptability terkait dengan edukasi program dengan baik melalui sejumlah pendampingan agar produk KUR dapat diterima dengan baik oleh pelaku usaha mikro.

Penelitian ini terkait dengan analisis kesediaan menggunakan KUR yang dijelaskan dengan pandangan kognitif. Pemilihan KUR ini merupakan pembuatan keputusan rasionalis karena konsumen perlu melakukan pertimbangan terlebih dahulu untuk menggunakan KUR. Konsumen perlu untuk mencari informasi dan menumbuhkan persepsi positif terkait dengan penggunaan KUR. Hal ini akan berimplikasi pada risiko penggunaannya di kemudian hari. Dalam riset ini, perilaku masyarakat pelaku usaha mikro dalam penggunaan KUR dapat dijelaskan 
dengan konteks perilaku konsumen yang bisa dipengaruhi oleh faktor eksternal konsumen yaitu kemudahan yang diberikan oleh pemasar sebagai penyedia jasa.

Dari latar belakang yang telah dipaparkan, maka rumusan masalah dalam penelitian ini adalah (1) Bagaimana pengaruh availability (ketersediaan) pada kesediaan menggunakan KUR? (2) Bagaimana affordability (dapat terjangkau) pada kesediaan menggunakan KUR? (3) Bagaimana awareness (kesadaran) pada kesediaan menggunakan KUR? dan (4) Bagaimana acceptability (dapat diterima) pada kesediaan menggunakan KUR? Sebaiknya bisa dijadikan 1 kalimat.

Tujuan penelitian ini adalah untuk menganalisis penerapan pendekatan 4As dengan empat elemen yaitu availability (ketersediaan), affordability (bisa terjangkau), awareness (kesadaran), dan acceptability (bisa diterima) yang memengaruhi kesediaan menggunakan kredit keuangan mikro. Studi ini bertujuan memberikan pandangan bagi pembuat keputusan yang lebih tinggi yaitu perusahaan dan pemerintah daerah untuk menyusun strategi peningkatan kesediaan untuk menerima kredit agar kesejahteraan masyarakat dapat meningkat lebih baik. Manfaat KUR bagi pelaku usaha mikro adalah membantu pembiayaan yang dibutuhkan untuk mengembangkan kegiatan usahanya. Manfaat penelitian ini adalah tercapainya percepatan pengembangan sektor riil dan pemberdayaan pelaku usaha mikro dalam rangka pengentasan kemiskinan dan perluasan kesempatan kerja serta pertumbuhan ekonomi.

Menurut Vida (2007), konsep "kesediaan menggunakan" merupakan konsep yang relevan dengan konsep "niat" pada teori Reasoned Action atau Planned Behavior. Penelitian Ajzen (1991) menyimpulkan bahwa sikap (Attitude) terhadap perilaku (behavior) biasanya memprediksikan niat perilaku (behavioral intention) dengan tingkat akurasi yang tinggi, bersamaan dengan norma subjektif dan persepsi yang mengontrol perilaku. "Kesediaan menggunakan" merupakan motivasi untuk menggunakan produk yang ditawarkan. Produk yang ditawarkan di sini memiliki aspek teknologi baru dengan sejumlah atribut yang mampu meningkatkan kinerja, tetapi di sisi lain ada keraguan dalam diri konsumen untuk mencobanya. Conrad menyatakan bahwa orang akan menggunakan teknologi baru (willingness to use) ketika mereka memiliki persepsi bahwa teknologi itu memiliki atribut keuntungan relatif (relative advantage) yang tinggi, kompleksitas yang rendah dan mudah digunakan, serta memiliki "trialability" yang tinggi (Conra dkk, 2012). Penelitian Chang (2010) menyimpulkan bahwa Willingness to Use (WTU) atau "kemauan menggunakan" merupakan perwujudan sikap positif terhadap sesuatu. Sikap positif seseorang terhadap suatu sistem dapat mengindikasikan bahwa orang tersebut tidak memiliki hambatan untuk menerima dan menggunakan sistem baru tersebut.

Konsep 4As merupakan konsep yang ditujukan agar mendukung kesuksesan implementasi strategi pemasaran untuk target konsumen (Suthar dkk, 2013). Konsep 4As ini merupakan tujuan yang akan dicapai dan dapat dibandingkan dengan $4 \mathrm{P}$ yaitu product, price, place, dan promotion. Akan tetapi, 4P terkait dengan implikasi dari strategi pemasaran (Sheth dan Shah, 2003). Konsep 4As terdiri atas availability (ketersediaan), affordability (dapat terjangkau), awareness (kesadaran), dan acceptability (dapat diterima). Konsep ini dikemukakan oleh Anderson dan Billou (2007). Konsep ini dianggap mampu menjelaskan penggunaan kredit keuangan mikro.

Availability didefinisikan sebagai persepsi kemudahan untuk mendapatkan produk terkait keberadaan produk. Saluran distribusi untuk masyarakat rural cenderung bersifat terfragmentasi dan untuk mendapatkannya biasanya cenderung sulit karena disebabkan oleh adanya aspek infrastruktur yang tidak bagus. Masyarakat rural memiliki kendala infrastruktur yang tidak bagus (Kaufmann dkk, 2007). Perusahaan diharapkan dapat melakukan cara atau menerapkan metode untuk menyampaikan produk atau jasa ke daerah yang cenderung terpencil. Persepsi terkait dengan ketiadaan produk akan membuat individu dalam masyarakat merasa kesulitan dalam melakukan akses produk. Keberadaan institusi keuangan yang bersifat inklusif menjadi indikator 
kemudahan bagi pelaku usaha untuk melakukan akses peminjaman (Sahoo dan Gomkale, 2015). Penelitian (Sawant $d k k$, 2013) menunjukkan bahwa adanya teknologi membuka kesempatan pelaku usaha untuk menggunakan saluran baru layanan perbankan. Teknologi perbankan mendukung jumlah volume transaksi perbankan online terus mengalami peningkatan. Layanan online memberikan kemudahan konsumen untuk mendapatkan informasi. Terkait dengan penggunaan KUR sebagai produk perbankan, masyarakat pelaku usaha mikro diharapkan memiliki persepsi kemudahan adanya akses terhadap produk tersebut. Apabila produk tersebut ada di daerah sekitar tempat tinggal masyarakat, maka akan mudah bagi masyarakat untuk melakukan pemilihan produk tersebut. Banyak perusahaan perbankan di Indonesia sudah mengarah ke daerah-daerah terpencil untuk dapat menawarkan produk keuangan agar membantu masyarakat untuk dapat mengakses keuangan. Adanya evaluasi sikap positif dan kemudahan mendapatkan produk akan menguatkan kesediaan menggunakan produk.

Affordability diartikan sebagai sejauh mana perusahaan dipersepsi mampu menawarkan produk atau jasa yang bisa dijangkau oleh masyarakat pelaku usaha mikro. Konsep ini juga dikaitkan dengan harga artinya kemampuan dari konsumen untuk melakukan pembayaran. Menurut Casassus bahwa konsumen akan membutuhkan permintaan tinggi bila harga dapat dijangkau atau rendah (Casassus dkk, 2009). Masyarakat pelaku usaha mikro memiliki tingkat pendapatan rendah dan keterbatasan akses diri. Perusahaan diharapkan mampu menawarkan produk atau jasa dengan harga terjangkau. Kemampuan masyarakat untuk mendapatkan produk atau jasa tergantung pada kemampuannya untuk membayar. Sheth dan Sisodia (2012) juga berpendapat bahwa affordability diartikan sebagai kemauan secara ekonomi dan psikologi konsumen untuk bersedia mengupayakan melakukan pembayaran atas produk yang ditawarkan. Aspek ekonomi merupakan kemampuan konsumen untuk membayar berdasarkan kemampuan pendapatan dan sumber daya yang dimiliki sedangkan aspek psikologi dikaitkan dengan kesediaan membayar karena adanya nilai atau manfaat lebih yang didapatkan. Terkait dengan penggunaan KUR sebagai produk perbankan, kemudahan untuk melakukan pembayaran bagi masyarakat pelaku usaha mikro sangat menentukan. Dengan sedikitnya kemampuan membayar, perusahaan yang memberikan suku bunga rendah atau kemudahan cara pembayaran akan memudahkan masyarakat dalam menggunakan kredit keuangan mikro. Evaluasi positif akan adanya manfaat yang nanti dirasakan menguatkan konsumen untuk bersedia menggunakan produk.

Awareness terkait dengan sejauh mana konsumen memiliki pengetahuan atau paham mengenai produk atau jasa yang ditawarkan (Keller, 2003). Kesadaran masyarakat terkait dengan adanya informasi baru sangat menentukan bagi masyarakat untuk menentukan pilihan produk atau jasa. Apabila tingkat kesadaran masyarakat rendah, maka akan sulit bagi masyarakat untuk menerima berbagai produk atau jasa yang ditawarkan. Penggunaan berbagai media dapat digunakan oleh perusahaan untuk memberikan informasi kepada masyarakat pelaku usaha mikro. Media yang dapat digunakan oleh perusahaan menyasar kelas masyarakat dengan menggunakan pemuka masyarakat atau opinion leadership. Awareness juga berhubungan dengan pengetahuan produk. Konsumen dalam memilih produk akan melakukan evaluasi berdasarkan pemahaman akan produk tersebut dan pemahaman tersebut akan berpengaruh kepada proses pencarian informasi konsumen, sikap, dan kuantitas informasi. Menurut Zhu (2004), pengetahuan produk memiliki hubungan dengan pengetahuan konsumen dalam mengenali produk. Pengetahuan konsumen akan suatu produk menentukan keputusan konsumen dalam pembelian yang secara positif memengaruhi kesediaan untuk menggunakan. Pengetahuan produk memiliki hubungan yang positif dengan jumlah informasi yang dimiliki oleh konsumen (Hanzaee dan Khosrozadeh, 2011). Kuantitas pengetahuan konsumen tidak hanya berguna untuk pencarian informasi, tetapi 
juga memiliki pengaruh pada pengambilan keputusan. Terkait dengan penggunaan KUR sebagai produk perbankan, perlu kesadaran dari masyarakat untuk memiliki keinginan menggunakan produk. Kesadaran ini terkait dengan pengetahuan atau informasi yang diperoleh masyarakat pelaku usaha mikro sehingga menguatkan pemahaman terhadap manfaat produk kredit keuangan mikro. Penguatan kesadaran ini didorong oleh adanya informasi dan pengetahuan yang diterima masyarakat.

Acceptability merupakan konsep yang menjelaskan sejauh mana individu mau menerima produk atau jasa. Dalam masyarakat pelaku usaha mikro, produk atau jasa sering disesuaikan sesuai dengan karakteristik konsumen. Perusahaan perlu melakukan modifikasi dalam penawaran produk atau jasa denganmenyesuaikankarakteristikatau kondisi lokal pedesaan. Menurut Subrahmanyan dan Gomez-Arias (2008), setiap bauran pemasaran untuk masyarakat, pelaku usaha melakukan modikasi untuk menyesuaikan dengan kondisi masyarakat. Terkait dengan produk, produk dibuat melalui modifikasi sederhana dan memiliki atribut yang agak berbeda dari produk lainnya agar memudahkan masyarakat untuk menggunakan. Sheth dan Sisodia (2012) berpendapat bahwa acceptability merupakan kemauan untuk menerima produk yang dirasa melebihi dari harapan konsumen. Ada dua dimensi dari acceptability yaitu aspek fungsional dan psikologis. Aspek fungsional terkait dengan manfaat utama sebuah produk terkait dengan atribut-atribut yang dimiliki untuk memenuhi kebutuhan manusia sedangkan aspek psikologis terkait dengan aspek psikis yang ditawarkan oleh pemasar yang meliputi aspek emosional, sosial, dan risiko. Aspek fungsional dan psikologis merupakan bagian nilai produk yang ditawarkan oleh pemasar. Terkait dengan penggunaan KUR sebagai produk inovatif, kemampuan produk kredit keuangan mikro dapat diterima adalah persepsi bisa diterimanya produk tersebut. Apabila masyarakat pelaku usaha mikro mempersepsikan adanya manfaat produk kredit keuangan dan memiliki modifikasi atribut atau manfaat sesuai dengan kebutuhan masyarakat, maka produk kredit keuangan akan mudah untuk diterima. Produk kredit keuangan diharapkan dapat memiliki modifikasi terkait dengan suku bunga, cicilan, dan media pembayaran.

Berdasarkan uraian teori tersebut, kerangka pemikiran yang dikembangkan dan diuji dalam penelitian ini adalah sebagai berikut.

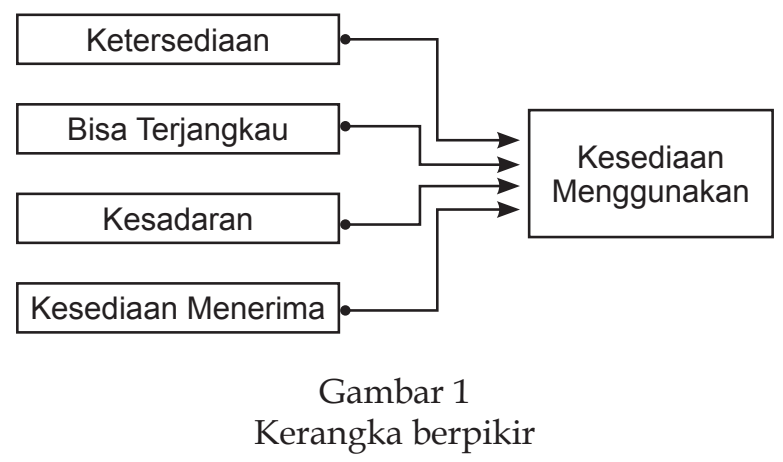

Objek penelitian dalam penelitian ini adalah individu pemilik usaha mikro, kecil atau menengah. Menurut Peraturan Menteri Koordinator Bidang Perekonomian Selaku Ketua Komite Kebijakan Pembiayaan Bagi Usaha Mikro, Kecil, dan Menengah Nomor 4 Tahun 2015, Usaha Rakyat (KUR) Mikro adalah kredit/pembiayaan modal kerja dan investasi kepada debitur di bidang usaha yang produktif dan layak, tetapi dengan belum memenuhi persyaratan agunan tambahan Bank Pelaksana plafon kredit sampai dengan Rp25.000.000,00 yang dijamin oleh Perusahaan Penjamin. Sumber dana penyaluran KUR Mikro adalah 100\% dari Bank Pelaksana KUR. KUR Mikro disalurkan oleh Bank Pelaksana dan dijamin secara langsung oleh Perusahaan Penjamin. Pengambilan sampling dipilih dengan menggunakan purposive sampling dengan kriteria yaitu individu sebagai masyarakat pelaku usaha mikro yang sudah menggunakan kredit keuangan mikro dalam satu tahun terakhir. Populasi penelitian ini terkait dengan pelaku usaha kecil menengah di Wilaya Jawa dan Bali. Wilayah penelitian meliputi Kendal, Semarang, Kudus, Jepara, Pati, Purwodadi, dan Denpasar. Jumlah responden yang terlibat sebanyak 500 
orang pelaku usaha mikro. Pengambilan data dilakukan pada Juni 2017 hingga Agustus 2017.

Penelitian ini menggunakan pendekatan kuantitatif untuk menganalisis penggunaan kredit keuangan mikro. Metode pengumpulan data dilakukan melalui survei dengan mengirimkan atau memberikan kuesioner kepada 500 pelaku usaha mikro. Penyebaran kuesioner dilakukan secara tatap muka dengan memberikan pertanyaan kepada responden terkait penggunaan kredit keuangan mikro. Dalam mengisi kuesioner, pelaku usaha mikro juga disediakan pendampingan dalam mengisi kuesioner agar memudahkan mereka. Pengukuran konsep availability, affordability, acceptability, dan awareness mengembangkan konsep yang disusun oleh Anderson dan Billou (2007). Semua variabel menggunakan skala pengukuran Likert 1 (satu) sampai 5 (lima). Angka 1(satu) menunjukkan sangat tidak setuju; angka 2 (dua) menunjukkan tidak setuju; angka 3 (tiga) menunjukkan netral; angka 4 (empat) menunjukkan setuju, dan angka 5 (lima) menunjukkan sangat setuju. Pertanyaanpertanyaan pada seluruh bagian pendekatan kuantitatif ini adalah close ended question dan scaled response questions. Data dianalisis dengan menggunakan regresi berganda.

\section{PEMBAHASAN}

Pelaku usaha sekaligus pengguna KUR didominasi oleh pria sebanyak 333 orang dari 498 total responden yang ada, sedangkan pelaku usaha wanita sebanyak 163 orang. Berdasarkan tingkat pendidikan pada Tabel $1,51 \%$ responden merupakan pelaku usaha dengan latar belakang pendidikan SMU/SMK dan diikuti dengan $19,88 \%$ pelaku usaha dengan latar belakang Sarjana Strata 1. Data demografi ini menunjukkan bahwa pelaku usaha relatif menciptakan pekerjaan tanpa meneruskan pendidikan ke tingkat yang lebih tinggi.

Tabel 1

Jenis kelamin dan Tingkat pendidikan.

\begin{tabular}{lll}
\hline \multicolumn{1}{c}{ Jenis Kelamin } & \multicolumn{1}{c}{ Frekuensi } & \multicolumn{1}{c}{ Persentase } \\
\hline Pria & 333 & $66,87 \%$ \\
Wanita & 163 & $32,73 \%$ \\
Blank & 2 & $0,40 \%$
\end{tabular}

Lanjutan Tabel 1.

\begin{tabular}{lll}
\hline \multicolumn{1}{c}{ Jenis Kelamin } & \multicolumn{1}{c}{ Frekuensi } & Persentase \\
\hline Tingkat Pendidikan & & \\
Tidak sekolah & 2 & $0,40 \%$ \\
Sekolah Dasar & 35 & $7,03 \%$ \\
Sekolah Menengah & 64 & $12,85 \%$ \\
SMU/SMK & 254 & $51,00 \%$ \\
Diploma 3 & 39 & $7,83 \%$ \\
Sarjana 1 & 99 & $19,88 \%$ \\
Sarjana 2 & 3 & $0,60 \%$ \\
\hline
\end{tabular}

Sebanyak 365 orang $(73,29 \%)$ memiliki usaha perdagangan; $6(5,22 \%)$ orang memiliki usaha manufaktur; 80 orang $(16,06 \%)$ bergerak di bidang pertanian; 26 orang $(1,81 \%)$ bergerak di bidang transportasi, dan 12 orang $(16,06 \%)$ bergerak di bidang lainnya. Usaha lainnya antara lain meliputi budidaya ikan, asesoris, laundry, catering, kelontong, bengkel, kosmetik, konveksi, kost, jilbab, rumah makan, service, supplier bahan, advertising, furniture, jasa pembimbingan belajar, toko pertanian, warung makan, kuningan, jasa las, sewa sound system, pengisian nitrogen, leveransir, ekspedisi, jasa kecantikan, counter HP, persewaan tratak, rental mobil, operator, reparasi, dan jasa penyedia tenaga kerja. Tabel 2 menunjukkan linieritas terkait dengan lama usaha didirikan. Sebanyak 161 usaha (32,22\%) baru berdiri 1(satu) hingga 5 (lima) tahun, 180 usaha $(36,14 \%)$ berdiri selama 6-10 tahun, 81 usaha $(16,27 \%)$ berdiri 11-15 tahun, 55 usaha $(11,04 \%)$ berdiri selama 16-20 tahun, 15 (3,01\%) usaha berdiri selama lebih dari 20 tahun, dan sisanya 6 (enam) usaha tidak diketahui lama usahanya.

Tabel 2

Lama Usaha Berdiri

\begin{tabular}{lll}
\hline Lama Usaha Berdiri & Frekuensi & Persentase \\
\hline 1-5 tahun & 161 & $32,22 \%$ \\
6-10 tahun & 180 & $36,14 \%$ \\
11-15 tahun & 81 & $16,27 \%$ \\
16-20 tahun & 55 & $11,04 \%$ \\
$>$ 20 tahun & 15 & $3,01 \%$ \\
Blank & 6 & $1,20 \%$ \\
\hline
\end{tabular}

Tabel 3 menunjukkan bahwa 69,48\% responden setuju bahwa Pemerintah menyediakan kemudahan pendanaan KUR kepada pelaku usaha mikro. $71,32 \%$ responden setuju 
bahwa banyak perusahaan Perbankan menawarkan KUR untuk pelaku usaha mikro. $68,97 \%$ responden setuju bahwa banyak perusahaan non-perbankan menawarkan kredit kepada pelaku usaha mikro. Dengan demikian, responden menyadari bahwa adanya ketersediaan pendanaan memudahkan usaha bisnis bagi responden. Hal ini terlihat dari pernyataan bahwa banyak institusi membantu dalam bentuk pemberian fasilitas pendanaan.

Tabel 3

Frekuensi untuk Pilihan Ketersediaan KUR

\begin{tabular}{llllll}
\hline \multicolumn{1}{c}{ Pernyataan } & \multicolumn{1}{c}{ TT (1) } & \multicolumn{1}{c}{ STS (2) } & \multicolumn{1}{c}{ TS (3) } & \multicolumn{1}{c}{ S (4) } & \multicolumn{1}{c}{ SS (5) } \\
\hline Pemerintah menyediakan kemudahan pendanaan & 2 & 1 & 3 & 346 & 144 \\
KUR kepada pelaku usaha mikro. & $(0,40 \%)$ & $(0,20 \%)$ & $(0,60 \%)$ & $(69,48 \%)$ & $(28,92 \%)$ \\
Banyak perusahaan Perbankan menawarkan KUR & 11 & 2 & 25 & 342 & 116 \\
untuk pelaku usaha mikro. & $(2,21 \%)$ & $(0,40 \%)$ & $(5,02 \%)$ & $(68,97 \%)$ & $(23,92 \%)$ \\
Banyak perusahaan non-perbankan menawarkan & 29 & 9 & 55 & 300 & 103 \\
kredit kepada pelaku usaha mikro. & $(5,82 \%)$ & $(1,81 \%)$ & $(11,04 \%)$ & $(60,24 \%)$ & $(20,68 \%)$ \\
\hline
\end{tabular}

Tabel 4 menunjukkan adanya upaya yang mudah untuk mendapatkan KUR. 68,07\% responden setuju bahwa pemerintah memberikan kemudahan yang bisa dijangkau oleh pelaku usaha dalam mengajukan KUR. $66,87 \%$ responden setuju bahwa banyak perusahaan perbankan menawarkan produk atau jasa yang bisa dijangkau oleh pelaku usaha mikro/kecil. 70,48\% responden setuju bahwa sebagai pelaku usaha mikro/kecil memiliki akses pendanaan yang mudah. Hal ini menunjukkan bahwa Pemerintah berusaha untuk memberikan akses kemudahan pendanaan bagi pelaku usaha mikro, kecil, dan menengah untuk mendukung usaha bisnis.

Tabel 4

Frekuensi untuk Upaya Mendapatkan KUR

\begin{tabular}{|c|c|c|c|c|c|}
\hline Pernyataan & TT (1) & STS (2) & TS (3) & $S(4)$ & SS (5) \\
\hline $\begin{array}{l}\text { Pemerintah memberikan kemudahan yang bisa } \\
\text { dijangkau oleh pelaku usaha mengajukan KUR. }\end{array}$ & $\begin{array}{l}2 \\
(0,40 \%)\end{array}$ & $\begin{array}{l}0 \\
(0 \%)\end{array}$ & 7 & $\begin{array}{l}339 \\
(68,07 \%)\end{array}$ & $\begin{array}{l}148 \\
(29,72 \%)\end{array}$ \\
\hline $\begin{array}{l}\text { Banyak perusahaan Perbankan menawarkan } \\
\text { produk atau jasa yang bisa dijangkau oleh pelaku } \\
\text { usaha mikro/kecil. }\end{array}$ & $\begin{array}{l}15 \\
(3,01 \%)\end{array}$ & $\begin{array}{l}2 \\
(0,40 \%)\end{array}$ & $\begin{array}{l}24 \\
(4,82 \%)\end{array}$ & $\begin{array}{l}333 \\
(66,87 \%)\end{array}$ & $\begin{array}{l}122 \\
(24,50 \%)\end{array}$ \\
\hline $\begin{array}{l}\text { Saya sebagai pelaku usaha mikro/kecil memiliki } \\
\text { akses pendanaan dengan mudah. }\end{array}$ & $\begin{array}{l}4 \\
(0,80 \%)\end{array}$ & $\begin{array}{l}1 \\
(0,20 \%)\end{array}$ & $\begin{array}{l}9 \\
(1,81 \%)\end{array}$ & $\begin{array}{l}351 \\
(70,48 \%)\end{array}$ & $\begin{array}{l}130 \\
(26,10 \%)\end{array}$ \\
\hline
\end{tabular}

Tabel 5 menunjukkan terkait pemahaman atas KUR. 64,46\% responden setuju bahwa mereka mengetahui produk KUR, 67,07\% responden setuju mengenai manfaat produk
KUR, dan 67,87\% setuju bahwa informasi KUR dapat diketahui dengan mudah. Hasil ini menunjukkan bahwa pelaku usaha ini mendapatkan banyak informasi terkait dengan penggunaan KUR.

Tabel 5

Frekuensi untuk Pemahaman KUR

\begin{tabular}{llllll}
\hline \multicolumn{1}{c}{ Pernyataan } & TT (1) & STS (2) & \multicolumn{1}{c}{ TS (3) } & \multicolumn{1}{l}{ S (4) } & \multicolumn{1}{c}{ SS (5) } \\
\hline Saya mengetahui produk Kredit Usaha & 5 & 0 & 6 & 321 & 164 \\
Rakyat. & $(1,00 \%)$ & & $(1,20 \%)$ & $(64,46 \%)$ & $(32,93 \%)$ \\
Saya memahami manfaat produk Kredit & 5 & 0 & 2 & 344 & 155 \\
Usaha Rakyat. & $(1 \%)$ & & $(0,40 \%)$ & $(67,07 \%)$ & $(31,12 \%)$ \\
Informasi Kredit Usaha Rakyat dapat & 4 & 2 & 5 & 338 & 147 \\
diketahui dengan mudah. & $(0,33 \%)$ & $(0,40 \%)$ & $(1,00 \%)$ & $(67,87 \%)$ & $(29,52 \%)$ \\
\hline
\end{tabular}


Tabel 6 menunjukkan kesediaan menerima KUR. 59,84\% responden menyatakan bahwa tidak merasa keberatan dengan keberadaan KUR dan 39,56\% responden sangat setuju akan hal tersebut. 57,03\% responden setuju bahwa pelaku usaha merasa terbantu atas keberadaan KUR dan $42,17 \%$ responden sangat setuju akan hal tersebut. 58,42\% responden merasa nyaman dengan keberadaan KUR dan 40,56\% responden sangat setuju akan hal tersebut. Dengan demikian, para responden merasa bahwa KUR dirasakan sangat membantu dalam mendukung kegiatan usaha. KUR dipersepsikan tidak memberatkan dalam pembiayaannya.

Tabel 6

Frekuensi untuk Kesediaan Menerima KUR

\begin{tabular}{clllll}
\hline \multicolumn{1}{c}{ Pernyataan } & \multicolumn{1}{c}{ TT (1) } & \multicolumn{1}{c}{ STS (2) } & \multicolumn{1}{c}{ TS (3) } & \multicolumn{1}{c}{ S (4) } & \multicolumn{1}{c}{ SS (5) } \\
\hline Saya tidak keberatan dengan keberadaan KUR & 0 & 0 & 0 & 298 & 1970 \\
Saya merasa terbantu dengan keberadaan KUR & $(0 \%)$ & $(0 \%)$ & $(0 \%)$ & $(59,84 \%)$ & $(39,56 \%)$ \\
& $(0,20 \%)$ & $(0 \%)$ & $(0 \%)$ & $(57,03 \%)$ & $(42,17 \%)$ \\
Saya merasa nyaman dengan keberadaan KUR & 1 & 0 & 1 & 291 & 202 \\
& $(0,20 \%)$ & $(0 \%)$ & $(0,20 \%)$ & $(58,43 \%)$ & $(40,56 \%)$ \\
\hline
\end{tabular}

Tabel 7 menunjukkan analisis validitas data yang diuji menggunakan metode Confirmatory Factor Analysis (CFA) karena bertujuan untuk menguji apakah indikatorindikator yang dikonstruksikan secara unidimensional, tepat, dan konsisten serta menganalisis indikator-indikator yang dominan yang membentuk konstruk yang diteliti. Analisis CFA menggunakan prosedur rotasi varimax yang akan mengakibatkan setiap variabel asal mempunyai korelasi tinggi dengan faktor tertentu saja dan dengan faktor yang lain memiliki korelasi relatif rendah sehingga setiap faktor akan lebih mudah untuk diinterpretasikan. Kriteria signifikansi dari item pernyataan ini didasarkan pada signifikansi praktis dengan loading $\pm 0,3$ dianggap lebih signifikan dan $\geq 0,50$ dianggap sangat signifikan. Jika butir pernyataan tidak memenuhi persyaratan, maka dieliminasi dan butir pernyataan yang memiliki factor loading $\leq$ 0,30 juga akan dikeluarkan. Selain itu, penelitian ini menggunakan uji KMO (KaiserMeyer-Olkin Measure of Sampling Adequacy) dan Bartlett Test yang bertujuan untuk menguji ada atau tidaknya korelasi antara variabel. Nilai KMO bervariasi, mulai dari 0-1, sedangkan nilai yang dikehendaki harus $\geq 0,05$ maka dikatakan valid dan dianggap layak untuk dilakukan analisis selanjutnya. Terkait dengan reliabilitas, indikator dapat dikatakan reliabel jika indikator tersebut saat mengukur suatu indikator dalam waktu yang berbeda-beda dapat tetap menunjukkan hasil yang konsisten (Cooper and Schindler, 2014:260). Metode untuk melakukan uji reliabilitas dalam penelitian ini menggunakan Cronbach's Alpha. Hasil Cronbach's Alpha dapat dilihat dari hasil output yang dilakukan oleh perhitungan statistik dengan menggunakan SPSS. Output tersebut dapat diketahui nilai reliabilitas (Cronbach's Alpha) setiap variabel dengan koefisien $\geq 0,7$.

Tabel 7

Hasil Validitas dan Reliabilitas Data

\begin{tabular}{clcc}
\hline \multirow{2}{*}{ Indikator } & \multicolumn{1}{c}{ Skala } & $\begin{array}{c}\text { Factor } \\
\text { Loading }\end{array}$ & $\begin{array}{c}\text { Cronbach } \\
\text { Alpha }\end{array}$ \\
\hline \multirow{2}{*}{ available1 } & $\begin{array}{l}\text { Pemerintah menyediakan kemudahan pendanaan KUR kepada pelaku } \\
\text { usaha mikro. }\end{array}$ & 0,431 & 0,708 \\
available2 & $\begin{array}{l}\text { Banyak perusahaan Perbankan menawarkan KUR untuk pelaku usaha } \\
\text { mikro. }\end{array}$ & 0,759 \\
available3 & $\begin{array}{l}\text { Banyak perusahaan non-perbankan menawarkan kredit kepada pelaku } \\
\text { usaha mikro melalui tenaga penjual. }\end{array}$ & 0,537
\end{tabular}




\begin{tabular}{|c|c|c|c|}
\hline Indikator & Skala & $\begin{array}{l}\text { Factor } \\
\text { Loading }\end{array}$ & $\begin{array}{l}\text { Cronbach } \\
\text { Alpha }\end{array}$ \\
\hline afford1 & $\begin{array}{l}\text { Pemerintah memberikan kemudahan yang bisa dijangkau oleh pelaku } \\
\text { usaha mengajukan KUR. }\end{array}$ & 0,428 & 0,779 \\
\hline afford2 & $\begin{array}{l}\text { Banyak perusahaan Perbankan menawarkan produk atau jasa yang bisa } \\
\text { dijangkau oleh pelaku usaha mikro/kecil. }\end{array}$ & 0,447 & \\
\hline afford3 & $\begin{array}{l}\text { Saya sebagai pelaku usaha mikro/kecil memiliki akses pendanaan } \\
\text { dengan mudah. }\end{array}$ & 0,313 & \\
\hline aware1 & Saya mengetahui produk Kredit Usaha Rakyat. & 0,544 & 0,895 \\
\hline aware2 & Saya memahami manfaat produk Kredit Usaha Rakyat. & 0,748 & \\
\hline aware3 & Informasi Kredit Usaha Rakyat dapat diketahui dengan mudah. & 0,706 & \\
\hline accept1 & Saya tidak keberatan dengan keberadaan KUR & 0,721 & 0,952 \\
\hline accept2 & Saya merasa terbantu dengan keberadaan KUR & 0,816 & \\
\hline accept3 & Saya merasa nyaman dengan keberadaan KUR & 0,791 & \\
\hline willingness1 & Saya bersedia menggunakan KUR. & 0,851 & 0,918 \\
\hline willingness 2 & Saya bersedia memanfaatkan KUR di masa yang akan datang. & 0,882 & \\
\hline willingness 3 & Saya menerima penggunaan KUR untuk pendanaan kegiatan bisnis. & 0,873 & \\
\hline willingness 4 & Saya menerima menggunakan KUR untuk kegiatan pendanaan. & 0,812 & \\
\hline
\end{tabular}

Berdasarkan Tabel 8, pengujian statistik terhadap variabel ketersediaan (availability) dengan tingkat signifikansi sebesar $5 \%$, memiliki nilai signifikansi $(0,023)$ yang lebih kecil dari nilai $p<0,05$. Nilai uji tersebut dapat menjawab hipotesis 1 yakni Ho berhasil ditolak, sehingga variabel ketersediaan (availability) memengaruhi kesediaan menggunakan KUR secara signifikan. Pengujian statistik terhadap variabel upaya mendapatkan (affordability) dengan tingkat signifikansi sebesar 5\%, memiliki nilai signifikansi $(0,373)$ yang lebih besar dari nilai $p<0,05$. Nilai uji tersebut dapat menjawab hipotesis 2 (dua), yaitu Ho berhasil didukung, sehingga variabel bisa terjangkau (affordability) memengaruhi kesediaan menggunakan KUR, tetapi tidak signifikan. Peng- ujian statistik terhadap variabel kesadaran (awareness) dengan tingkat signifikansi sebesar $5 \%$, memiliki nilai signifikansi $(0,045)$ yang lebih kecil dari nilai $p<0,05$. Nilai uji tersebut dapat menjawab hipotesis 3 yakni Ho berhasil ditolak, sehingga variabel kesadaran (awareness) memengaruhi kesediaan menggunakan KUR secara signifikan. Pengujian statistik terhadap variabel kesediaan menerima (acceptability) dengan tingkat signifikansi sebesar 5\%, memiliki nilai signifikansi $(0,000)$ yang lebih kecil dari nilai $p<0,05$. Nilai uji tersebut dapat menjawab hipotesis 4 (empat), yaitu Ho berhasil ditolak, sehingga variabel kesediaan menerima (acceptability) memengaruhi kesediaan menggunakan KUR secara signifikan.

Tabel 8

Hasil Pengujian Hipotesis

\begin{tabular}{lcc}
\hline \multicolumn{1}{c}{ Hipotesis } & P values & Signifikansi \\
\hline $\begin{array}{l}\text { H1: Variabel ketersediaan (availability) memengaruhi kesediaan menggunakan } \\
\text { produk perbankan. }\end{array}$ & 0,023 & Signifikan \\
$\begin{array}{l}\text { H2: Variabel upaya mendapatkan (affordability) memengaruhi kesediaan } \\
\text { menggunakan produk perbankan. }\end{array}$ & 0,373 & Tidak signifikan \\
$\begin{array}{l}\text { H3: Variabel kesadaran (awareness) memengaruhi kesediaan menggunakan } \\
\text { produk perbankan. }\end{array}$ & 0,045 & Signifikan \\
$\begin{array}{l}\text { H4: Kesediaan menerima (acceptability) memengaruhi kesediaan } \\
\text { menggunakan produk perbankan. }\end{array}$ & 0,000 & Signifikan \\
\hline
\end{tabular}


KUR dirasakan sebagai fasilitas pemberian kredit yang murah oleh masyarakat, memiliki banyak manfaat, dan kemudahan dalam menggunakannya. Perilaku pelaku usaha mikro dalam penggunaan KUR dapat dijelaskan dengan konteks perilaku konsumen yang dapat dipengaruhi oleh faktor eksternal dan internal. Perilaku masyarakat dalam menggunakan kredit keuangan mikro dapat dianalisis dari perspektif eksternal dan internal. Riset ini lebih mengutamakan dari sisi internal masyarakat yaitu persepsi terhadap kegunaan kredit keuangan mikro. Persepsi ini terkait dengan menafsirkan stimuli terkait dengan penawaran kredit keuangan mikro. Persepsi ini bisa dipengaruhi oleh aspek latar belakang individu terkait dengan tingkat pendidikan, pengetahuan, budaya, pembelajaran, dan tentu saja kebutuhan. Terkait dengan tingkat pendidikan, pelaku usaha memiliki ratarata pendidikan dengan tingkat SMU/SMK sebanyak $51 \%$, sarjana sebanyak 19,88\%, dan diploma 3 (tiga) sebanyak 7,83\%. Terkait dengan lama berdiri perusahaan, 36,14\% usaha sudah berdiri selama 6-10 tahun dan 32,22\% usaha sudah berdiri selama 1hingga 5 tahun. Latar belakang usaha ini dan lama perusahaan memberikan pengetahuan bagi pelaku usaha untuk mendapatkan informasi terkait dengan fasilitas yang memudahkan pendanaan.

Adanya KUR ini menjadikan pengusaha mikro bisa memiliki keleluasaan dalam mengembangkan usahanya yang sebelumnya tidak dimiliki sama sekali. Semua pelaku usaha berasal dari Jawa dan Denpasar (hanya 5\%) menjadi responden. Responden juga menggunakan sebelumnya lembaga keuangan mikro sebanyak
11,04\%, 38,76\% mengikuti arisan, dan 90,36\% memiliki tabungan bank. Menurut studi Demirguc-Kunt dan Klapper (2012), masyarakat kecil di Jawa cenderung menerapkan arisan sebagai cara untuk mendapatkan pendanaan. Hal ini didukung dengan aspek penguatan komunitas dan dukungan budaya timur yang mendukung adanya kebersamaan. Konsep 4As mampu menjelaskan perilaku konsumen khususnya kesediaan menggunakan KUR untuk mendukung pendanaan dalam kegiatan usaha. Sheth dan Sisodia (2012) menjelaskan bahwa konsep tersebut merupakan konsep yang relevan dan tepat untuk menjelaskan adopsi produk inovatif khususnya untuk pelaku usaha mikro.

Terkait dengan aspek ketersediaan (availability), variabel ini memengaruhi kesediaan atas penggunaan KUR. Adanya pelaku usaha UMKM mendorong perekonomian Indonesia lebih maju. Peluang kredit mikro ini sangat besar bagi pelaku usaha di Indonesia. $70 \%$ adalah sektor informal. Nilai penyaluran kredit UMKM dari waktu ke waktu mengalami kenaikan sejak tahun 2012. Adanya tren positif ini menunjukkan bahwa UMKM merupakan peluang pasar bagi perbankan dan fintech untuk memberikan kemudahan pembiayaan (Rachman, 2017). Tabel 9 menunjukkan sejumlah pemain dalam bidang kredit UMKM. Banyaknya pemain ini menunjukkan adanya ketersediaan dan aksesibilitas dalam mendapatkan pendanaan. Selain perbankan, sejumlah penyedia jasa keuangan dalam bentuk Fintech juga semakin beragam yaitu Modalku, Investree, Uangteman, Koinworks, Pinjam, dan Amartha.

Tabel 9

Keberadaan Bank Penyedia KUR

\begin{tabular}{|c|c|c|}
\hline No & Nama Bank & Keterangan \\
\hline 1. & Bank BRI & Pemberian kredit mikro, KUR, dan UKM per Maret 2017. \\
\hline 2. & Mandiri & $\begin{array}{l}\text { Pemberian kredit UMKM, KUR, Kredit Usaha Mikro, dan Kredit Serbaguna Mikro } \\
\text { per Maret } 2017 .\end{array}$ \\
\hline 3. & BNI & Kredit segmen kecil (KUR dan Non-KUR). \\
\hline 4. & BCA & Pemberian kredit UKM sepanjang tahun 2016. \\
\hline 5. & Panin Bank & $\begin{array}{l}\text { Pemberian Kredit Perbankan Komersial meliputi Small Medium Business, Consumer, } \\
\text { Kredit Mikro Panin. }\end{array}$ \\
\hline
\end{tabular}


Lanjutan Tabel 9.

\begin{tabular}{|c|c|c|}
\hline No & Nama Bank & Keterangan \\
\hline 6. & Bank Bukopin & $\begin{array}{l}\text { Kredit Mikro (kredit modal tidak tetap swamitr, kredit pensiunan, kredit pra- } \\
\text { pensiun) dan kredit UKM. }\end{array}$ \\
\hline 7. & CIMB Niaga & Kredit UKM, Mikro Linkage, Mikro Laju, Pinjaman Pensiun. \\
\hline 8. & Danamon & Penyaluran kredit perbankan UKM dan portfolio kredit mikro. \\
\hline 9. & Maybank & Kredit mikro terdiri atas PIJAR-Pilihan Bijak Mitra Usaha dan Program Sahabat BPR. \\
\hline 10. & BTPN & Pemberian kredit berdasarkan segmen UMKM. \\
\hline 11. & OCBC NISP & Pemberian kredit segmen EMB-Emerging Business Banking. \\
\hline 12. & Permata Bank & Kredit UMK. \\
\hline 13. & Bank Mega & Kredit Ritel terdiri atas Kredit SME dan Consumer. \\
\hline 14. & Mandiri Taspen Pos & Kredit Usaha Mikro terdiri atas KUM, KSM, dan KKM. \\
\hline 15. & Bank BTN & Kredit UMKM (KUR, KUMK, Kredit Investasi, KMK, dan KMK Kontraktor). \\
\hline 16. & Bank BJB & Pemberian Kredit UMKM. \\
\hline 17. & Bank Jatim & $\begin{array}{l}\text { Kredit mikro Laguna, Kredit Linkage Program BPR, Kredit Usaha Rakyat (KUR), dan } \\
\text { KUMK. }\end{array}$ \\
\hline 18. & Bank DKI & Kredit Mikro \\
\hline
\end{tabular}

Sumber: Majalah SWA Juni, XXIII (2017)

Keberadaan bank dalam menyediakan layanan KUR bisa menciptakan aksesibilitas responden dalam menentukan pilihan produk. Penelitian ini mendukung penelitian Desai dan Hoyer (2000) yang menunjukkan bahwa konsumen akan memiliki aksesibilitas terhadap informasi merek karena adanya paparan informasi melalui berbagai media dan saluran. Media ini berfungsi memengaruhi consideration set dengan cara menampilkan kembali merek yang ada dalam memori dan membuat konsumen sadar untuk mempertimbangkan merek yang dipilih untuk pembelian berikutnya. Aksesibilitas merek dalam consideration set memudahkan konsumen untuk mempertimbangkan merek-merek yang menjadi pilihan pembelian berikutnya. Informasi merek yang bertambah membuat konsumen bisa menentukan pilihan lain suatu merek dengan mudah. Tabel 9 menunjukkan adanya sejumlah keberadaan pelayanan KUR yang ditawarkan melalui berbagai media yang memudahkan konsumen menentukan pilihan. Perbankan dengan mudah memberikan informasi dengan menggunakan berbagai media antara lain situs, koran, dan memanfaatkan sales force perusahaan. Data penelitian ini juga menunjukkan bahwa ada peran salesforce yang kuat dari masing-masing perbankan yang menawarkan KUR, sehingga responden tidak memiliki kesulitan dalam menentukan jasa KUR.

Koefisien rata-rata variabel upaya mendapatkan (Affordability) ini sebesar 4,19 yang artinya rata-rata responden setuju terkait dengan usaha perusahaan untuk memberikan penawaran produk dan mempersepsikan akses pendanaan dengan murah. Berdasarkan analisis data, variabel upaya mendapatkan dinyatakan memiliki pengaruh kesediaan untuk menggunakan KUR, tetapi tidak signifikan. Berdasarkan konsep pembelajaran atau learning theory, konsumen sudah memiliki informasi terdahulu, sehingga akan mudah menerima hal baru (Solomon, 2018). Konsumen dapat menentukan keputusan lebih lanjut terkait dengan pilihan produk. Variabel upaya untuk mendapatkan pinjaman KUR dipersepsi tinggi, yang artinya bahwa para responden tidak memiliki kesulitan untuk mendapatkan akses pinjaman. Pelayanan bank dipersepsi sangat mudah memberikan informasi kepada konsumen. Konsumen merasa tidak perlu berupaya untuk mendapatkan informasi dan menguatkan sikap untuk menerima KUR karena konsumen sudah mendapatkan kemudahan akses KUR. Selain itu, para responden juga sudah memiliki pengalaman dalam menggunakan pelayanan perbankan, sehingga akan mudah bagi responden untuk menerima. 
Terkait dengan awareness, responden diketahui memiliki banyak pemahaman terkait dengan produk keuangan selain KUR. Hasil penelitian ini menjelaskan pengetahuan produk keuangan. Konsumen dalam penelitian ini memiliki aspek kesadaran. Aspek kesadaran ini bila dikaitkan dengan hierarki model komunikasi merupakan aspek yang berada dalam tahap kognitif. Tahapan kognitif ini menunjukkan pengetahuan konsumen terhadap informasi KUR. Produk-produk keuangan ini terkait dengan keberadaan produk lembaga keuangan mikro termasuk koperasi, BMT, arisan, kredit informal termasuk rentenir, pegadaian, tabungan bank, kredit bank termasuk kartu kredit, dan asuransi. Kesadaran atau awareness konsumen terhadap produk-produk keuangan merupakan bagian dari pengetahuan konsumen yang pada akhirnya akan menciptakan aspek afeksi untuk menentukan pilihan lebih lanjut. Penelitian ini mendukung penelitian Lim yang menguatkan bahwa pengetahuan produk akan berpengaruh pada niat konsumen untuk melakukan investasi pasar saham (Lim dkk, 2013). Pengetahuan produk akan meningkatkan keyakinan seseorang untuk membuat keputusan lebih baik. Konsumen yang memiliki pengetahuan produk yang baik akan menentukan keputusan yang lebih baik dibandingkan dengan konsumen yang memiliki tingkat pengetahuan yang rendah. Dengan demikian, para responden memiliki kesadaran yang baik yang akhirnya memengaruhi kesediaan menggunakan produk.

Terkait dengan acceptability, dalam penggunaan KUR dipersepsikan oleh pelaku usaha untuk menggunakan KUR. Kemauan menerima ini terkait dengan aspek pembiayaan yang memudahkan untuk menjalankan usaha yang merupakan bagian kinerja. Manfaat lain juga dirasa dapat menciptakan lapangan kerja termasuk membantu meningkatkan penjualan produk, membantu untuk mendapatkan pendapatan dari investasi (return on investment), memudahkan usaha bisnis dalam jangka pendek, memudahkan usaha bisnis dalam jangka panjang, mendukung proses bisnis, memudahkan perusahaan dalam melayani konsumen bahkan memudahkan perusahaan untuk bekerja sama dengan pemasok. Selain itu, kemauan untuk menerima penggunaan KUR secara tidak langsung bisa mengurangi kemiskinan karena memberikan kesempatan lapangan kerja. Penelitian ini mendukung penelitian Shirazi dan Khan (2014) dan Ahmed (2009) yang berpendapat bahwa perhatian pada kredit keuangan mikro penting untuk mengurangi tingkat kemiskinan. Mader (2014) berpendapat bahwa keuangan mikro dianggap sebagai cara untuk melepaskan kemiskinan yang paling bagus karena keuangan mikro merupakan hak kemanusiaan.

Secara umum, penelitian ini memberikan gambaran bahwa model 4As bisa menjelaskan kesediaan responden dalam hal ini nasabah KUR untuk menggunakannya, kecuali untuk variabel upaya mendapatkan (affordability). Model ini menunjukkan adanya perbedaan individu dengan latar belakang yang berbeda untuk menerima produk baru. Variabel ketersediaan (availability), kesadaran (awareness), dan kesediaan menerima (acceptability) mampu menjelaskan kesediaan pelaku usaha untuk menggunakan KUR. Hal ini didukung dengan relevansi model ini yang diterapkan untuk menjelaskan pelaku usaha di tingkat kecil dan mikro yang sesuai dengan ketepatan model dengan konteks penelitian. Indikator-indikator dalam variabel lebih mudah dipahami oleh responden terkait persepsi terhadap pelayanan produk perbankan, dalam hal ini KUR. Hasil ini mendukung penelitian Sheth dan Sisodia (2012) yang menjelaskan bahwa karakteristik pengusaha kelas kecil dan menengah untuk memudahkan pemahaman aspek yang memengaruhinya dalam membuat keputusan. Variabel-variabel dalam Model 4As merupakan sebuah stimuli yang dipersepsikan untuk diolah lebih lanjut dalam memori konsumen sehingga bisa menjadi penentu pilihan dalam pendanaan usaha.

\section{SIMPULAN}

Penelitian ini menunjukkan bahwa variabel ketersediaan (availability), kesadaran (awareness), dan kesediaan menerima (acceptability) mampu menjelaskan kesediaan 
pelaku usaha untuk menggunakan KUR. Aspek ketersediaan (availability) merupakan aspek yang bisa dikaitkan dengan distribusi produk. Kemudahan untuk mengembangkan relasi yang baik dengan konsumen akan memudahkan konsumen untuk menentukan pilihan produk. Distribusi produk KUR menciptakan aksesibilitas produk untuk konsumen baik melalui media online maupun offline. Terkait dengan media online, konsumen bisa melakukan akses situs untuk memahami informasi KUR beserta kemudahan dan prasyarat pengajuan. Media offline bisa diaktifkan dengan memanfaatkan keberadaan salesforce atau pemanfaatan media lain yang bisa menjadi saluran informasi bagi pelaku usaha. Pelaku usaha UMKM menunjukkan perkembangan dalam sisi jumlah. Jumlah pelaku usaha dengan skala Mikro, Kecil, dan Menengah (UMKM) mengalami pertumbuhan yang meningkat dari tahun ke tahun. Peningkatan jumlah dari tahun ke tahun menunjukkan bahwa perkembangan UMKM cukup bagus sebagai potensi pendukung perekonomian Indonesia. Perkembangan UMKM ini menjadi kontribusi perekonomian Indonesia. UMKM ini bisa mendorong peningkatan kesempatan tenaga kerja dan memberikan tambahan penghasilan bagi para pelaku usaha. Peningkatan kinerja UMKM ini dipengaruhi oleh banyak faktor. Salah satu faktor pendukung adalah pembiayaan kredit usaha. Potensi UMKM yang menunjukkan kinerja bagus ini didukung kemudahan akses biaya dari perbankan. Aspek kesadaran (awareness) merupakan aspek sikap yang terkait dengan kognitif konsumen. Hal ini mendukung terciptanya pengetahuan konsumen untuk membuat keputusan yang rasional mengenai manfaat atas produk yang akan dipilih dan konsekuensi penggunaannya. Aspek kesadaran ini bisa lebih diperkuat dengan memberikan edukasi program-program pelayanan perbankan bagi pelaku usaha, terutama untuk pelaku usaha UMKM yang belum menggunakan produk perbankan, KUR. Edukasi kepada konsumen bisa melalui pertemuan informal di kalangan pengusaha untuk mengetahui manfaat KUR dengan baik. Aspek kesediaan menerima (acceptability) merupakan bentuk sikap yang menunjukkan keyakinan akan manfaat KUR. Keyakinan ini akan menguatkan motivasi untuk menggunakan KUR. Pihak perbankan bisa menggunakan para pelaku usaha yang sukses atas penggunaan pendanaan KUR untuk mengajak para pelaku usaha yang belum memanfaatkan KUR. Para pelaku usaha ini bisa menjadi brand ambassador bank untuk menjelaskan manfaat KUR guna memperluas usaha dan meningkatkan kesejahteraan. Penelitian mendatang terkait dengan model 4As perlu dikuatkan kembali dengan memperluas kajian konsep. Analisis terkait dengan program KUR masih perlu dilakukan terkait dengan pelaksanaan program, nilai program, dan perilaku pasca penggunaan program KUR dari para pelaku usaha UMKM. Analisis lebih lanjut dalam penelitian ini akan mampu menjelaskan konsep-konsep kualitas jasa, nilai konsumen, konsumen, dan loyalitas konsumen terkait dengan Program KUR. Hasil penelitian Rokhim et al., (2017) memberikan banyak masukan terkait aspek manajerial terutama sikap dan nilai konsumen, dengan perlu menganalisis dari sisi sikap dan perilaku para pelaku usaha, sehingga penelitian lanjutan ini diharapkan bisa memberikan perbaikan dari sisi kebijakan, program-program pembinaan pelaku usaha, dan peningkatan pelayanan perbankan sebagai pengelola KUR.

\section{DAFTAR PUSTAKA}

Ahmed, S. 2009. "Microfinance institutions in Bangladesh: Achievements and challenges". Managerial Finance, 35(12): 999-1010.

Ajzen, I. 1991. "The theory of planned behavior". Organizational behavior and human decision processes, 50(2): 179-211.

Anderson, J. dan N. Billou, 2007. “Serving the world's poor: Innovation at the base of the economic pyramid". Journal of Business Strategy, (28): 14-21.

Bandura, A. 1986. Social Foundations of Thought and Action: A Social Cognitive Theory. Englewood: Prentice Hall. 
Casassus, J., P. Liu, dan K. Tang. 2009. Commodity Prices in the Presence of Inter-commodity Equilibrium Relationships. Working paper, Cornell University.

Chang, D. 2010. Examining The Factors That Influence Consumer's Willingness To Use A Restaurant Recommendation Agent. Rotterdam: Erasmus University.

Cooper, D. R. dan P. S. Schindler. 2011. Business Research Methods. 11th ed. New York: McGraw-Hill Irwin.

Conrad, E., M. Michalisin, dan S. Karau. 2012. "Measuring Pre-Adoptive Behaviors Toward Individual Willingness to use IT Innovations". Journal of Strategic Innovation and Sustainability, $8(1)$.

Davis, F.D. 1989. "Perceived usefulness, perceived ease of use, and user acceptance of information technology. Computer and Information Systems Graduate School of Business Administration University of Michigan Ann Arbor, Michigan 48109". MIS Quarterly.

Davis, F.D., R.P. Bagozzi, dan P.R. Warshaw. 1992. "Extrinsic and intrinsic motivation to use computers in the workplace". Journal of Applied Social Psychology, 22 (14): 1111-1132.

Demirguc-Kunt, dan L. Klapper. 2012. "Measuring financial inclusion: The global findex database". World Bank Policy Research Paper, 6025.

Desai, K.K., dan W.D. Hoyer. 2000. "Descriptive characteristics of memory based consideration sets: Influence of usage occasion frequency and usage location familiarity". Journal of Consumer Research, 27: 309-323.

Habib, M. dan L. Zurawicki. 2010. “The bottom of the pyramid: Key roles for businesses". Journal of Business $\mathcal{E}$ Economics Research, 8:23.
Hanzaee, K. H., dan S. Khosrozadeh, 2011. "The Effect of the Country-of-Origin Image, Product Knowledge". MiddleEast Journal of Scientific Research, 8 (3): 625-636.

Imai, K. S., T. Arun, dan S. K. Annim, 2010. "Microfinance and Household Poverty Reduction: New Evidence from India". World Development, 38(12): 1760-1774.

Keller, K.L. 2003. Brand synthesis: "The multidimensionality of brand knowledge". Journal of Consumer Research, 29: 595-600.

Kaufmann, D., A. Kraay, dan M. Mastruzzi. 2007. "Governance mattersVI: Governance indicators for 19962006". World Bank Policy Research Working Paper, 4280 (4280).

Kusuma, D. R. 2016. "11 Bank Ini Direkomendasikan Jadi Penyalur KUR." Detik. Diakses pada tanggal 7 Januari 2016. <https:// finance.detik.com/ moneter/d-3111110/11-bank-inidirekomendasikan-jadi-penyalur kur?_ga=2.225849562.1798373359. 1534353267-2000899765.153435 $3264>$.

Lim, K.L., G.N. Soutar, dan J.A. Lee. 2013. "Factors affecting investment intentions: A consumer behavior perspective". Journal of Financial Services Marketing, 18(4): 301-315.

Mader, P. 2014. "Financialisation through microfinance: Civil society and market building in India". Asian Studies Review, (38):601-619.

Rachman, V. Juni 2017. "Para jawaran di pembiayaan usaha mikro". Majalah SWA XXIII.

Rokhim, R., I. Mayasari, dan P.M. Desiana. 2017. Analisis pembuatan keputusan pelaku usaha mikro terhadap penggunaan produk kredit usaha rakyat. Tidak Dipublikasikan. 
Rogers, Everett M. 1995. Diffusion of Innovations. $4^{\text {th }}$ edition. New York: The Free Press.

Sahoo, M.K dan M. Gomkale. 2015. “Financial inclusion in India: An empirical study of unorganized sector in Gujarat". Information Management $\mathcal{E}$ Business Review, 7: 6-17.

Sawant, P., R.V. Kulkarni, dan S.D. Mundhe. 2013. "Customer satisfaction with e-banking: A comparative study of public and private sectors banks". IUP Journal of Bank Management, 12(4): 29-44.

Sethia, N. 2005. "At the bottom of the pyramid:Responsible design for responsible business". Design Management Review, (16):42.

Shah, C. dan R. Desai. 2013. "The 4As of rural marketing mix". International Journal of Management and Social Sciences Resarch, 2(1): 6-12.

Sheth, J.N. dan R.H. Shad. 2003. "Till death do us part... but not always: Six antecedents to a customer's relational preference in buyer-seller exchanges". Industrial Marketing Management, 32(8): 627-631.

Sheth, J.N. dan R.S. Sisodia, 2012. "The 4As of rural marketing mix". International Journal of Management and Sosial Sciences Research, 2(1).

Shirazi, N. S., dan A. U. Khan. 2014. "Role of Pakistan poverty alleviation fund's micro credit in poverty". Pakistan Economic and Social Review, 47(2): 215-228.

Solomon, M. R. 2018. Consumer behavior: Buying, having, and being. New Jersey: Prentice Hall.
Subrahmanyan, S. dan F.T. Gomez-Arias. 2008. "Integrated approach to understanding consumer behavior at bottom of pyramid". Journal of Consumer Marketing, (25): 402-412.

Suthar, B.K., T.L. Chakravarthi, dan S. Pradhan. 2013. "Assessing Effectiveness of Rural Marketing Mix in context to Bharat Sanchar Nigam, Vadodara Telecom District". Global Journal of Management and Business Studies, 3: 503-518.

Taylor, S. dan P.A. Todd. 1995. "Assesing IT usage: The role of prior experience". MIS Quarterly, 19(2): 561-570.

Thompson, R.L., C.A. Higgins, dan J.M. Howell. 1991. "Personal computing: Toward a conceptual model of utilization". MIS Quarterly, 15(1): 124-143.

Venkatesh, V., M.G. Morris, G.B. Davis, dan F.D. Davis. 2003. "User Acceptance Of Information Technology: Toward A Unified View". Management Information System, 27 (3): 425-478.

Vida, I. 2007. “Determinants of Consumer Willingness to Purchase NonDeceptive Counterfeit Products". Managing Global Transitions, 5 (3): 253-270.

Zhu, P.T. 2004. The relationship Among Community Identification, Community Tust, and Purchase Behavior The Case of RVs Communities. Masters Degree thesis, Shoufeng: Graduate School of International Business, National Dong Hwa University. 